\title{
Integral Andragogy as a Social Assistance
}

KEY WORDS

andragogy, pedagogy, integral andragogy, socialization, cultural capital, social capital

\begin{abstract}
Pavel Mühlpachr, Integral Andragogy as a Social Assistance [Andragogika integralna jako wspomaganie społeczne]. Kultura - Społeczeństwo - Edukacja nr 2, 2012, Poznań 2012, pp. 9-16, Adam Mickiewicz University Press. ISBN 978-83-232-2528-7

The paper presents the new conception of andragogical thinking, so called conception of integral andragogy. The concept of integral andragogy is founded on care, help and support for people within their life paths. It is possible to interpret this conception as mobilization of human capital in the environment of a social change.
\end{abstract}

The term Andragogy was created in the manner of the term Pedagogy (pais, paid-os = a boy) by similar broadening of the word anér, andr-os = a man, into an adult person + agogé = leadership, education (from agó, agein = lead, govern).

The term Andragogy originates already in the first half of the $19^{\text {th }}$ century. It was used for the first time by the German teacher Alexander Kapp in 1833. He talks about Andragogy or education in adulthood. The term is reestablished after one hundred years in 1924 by Rosenstock, who defines Andragogy as all institutional forms of adult education. It is probably the first attempt to separate the education of adults from the education of youth.

In the conditions of postmodern society, which is characterized by specific attributes, the definition of Integral Andragogy may be used for the purposes of special education.

The roots of andragogy could be found in the years following the end of second world war. Didactic theory of adult education is found in Germany, and also the concept of social andragogy, which is very close to the present form of andragogy.

If we come out from the sociologically tinged concept of education, the term andragogy will not be considered as only and unambiguously pedagogical. This opinion can be supported by another argument: Andragogy is also related to 
the tradition of normative and evaluative science about human behavior, which emerged in Holland in the 1940s and cannot be considered to be a pedagogical science. The theoretical basis of Andragogy was formulated by professor Ten Haven, who distinguished between Andragogy and Andragology, which is already a systematic branch of social science including its own methodological reasoning about practical activities with adults. It includes not only the theories of the educational impact on adults but also the theories of social work with adults. Wilfred Gottschalk defines Andragology twenty years later as a science about social behavior leading towards achieving appropriate and professional changes in thinking, feeling and acting of people.

The present andragogy appeared in the 1950s in the works of the Swiss theorist of adult education H. Hanselmann and the German classic of andragogy F. Pöggeler.

Heinrich Hanselmann postulates andragogy as a discipline with distinctive therapeutic focus on adults and with strong, even militant religious (Protestant) character. For work whit adults such as this, he requires the use of methods fundamentally different from the methods of educational work with youth, primarily abandoning all school forms. He stresses individual education on the basis of optionality, and instead of teacher's dominant role, he demands mutual interaction of both sides of the pedagogical relation.

The German concept of andragogy represented by Franz Pöggeler is also based on religious grounds (this time Catholic). This concept is strongly didactic contrary to the Hanselmann's socially andragogical concept. Pöggeler differentiates between education, which is a specific form of upringing of adults, and care and forming of character, which is typical only for children and youth. In this distinction Pöggeler sees the main difference between andragogy and pedagogy. In the specification, he essentially agrees with Hanselmann (optionality, informality, rejection of school forms and inadequate methods). They both rejected all forms of fostering adults: An adult cannot be fostered, because changes of personality cannot be achieved after the individual biological development is completed.

Andragogy was until recently seen in the Czech Republic only in the context of adult education, and was considered to be „a bourgeois unscientific deviation” of the theory of education of adults.

The term andragogy appeared only after 1990 as a designation of a science and a field of study, and also as a tendency to differ from improperly named and politically discredited field of study called „Education of adults”.

Andragogy is a new, dynamically growing discipline, and is therefore understandable, that it is often a topic of discussion and criticism. The main objections lead to several areas: 
- A major dispute over the fundamental or relative difference between the education of adults and education of children and youth, and the justifiability and necessity of andragogy as an independent science;

- A major doubt, not only pedagogical, but of the whole liberal stream of thinking, and even defiance to apply the term fostering on adults (Hannah Arendt): an adult is unfosterable after the formation of an individual personality, and all attempts to do so are not only impossible, but also inadmissible. It is strictly speaking a fundamental dispute between the Komensky understanding of lifelong education and Herbart understanding of education, as a support in growing up and refusal of any kind of education of adults (which would cause a general immaturity);

- There are disputes within andragogy itself, concerning its position among sciences of education and concerning its relation with pedagogy. Are they two independent fields, which have nothing in common, or are they two branches of the general science of education with only relative independence?

- There is also a debate, whether andragogy is a theory, ideology, or complex of instructions for practical adult education (or more broadly managing of adults);

- The content of andragogy is also disputable. Is it solely didactic and technological concept limiting andragogy to the theory and practice of education and teaching, or does it extend into education as an aggregate management and influence of adults.

The foundation of andragogy is, regardless to the above mentioned doubts, a reflection of the current stage of scientific and technological revolution of the second half of the $20^{\text {th }}$ century, primarily the development of education of adults, the concept of permanent education, lifelong education, lifelong learning, and also the growth of critical phenomena and the growth of problems concerning the position of an individual and care in the current civilization.

The dictionary of adult education defines andragogy as a science about fostering, care and education of adults, respecting by all means the uniqueness of adult population and dealing with personalization, socialization and enculturation. In the area of education, it deals with the unique effects of pedagogical laws on adult population, it defines adult personality in the process of education, defines the system of education of adult population, and also the relation of andragogy with other pedagogical and social sciences.

The broader definition of education states, that education is one of the basic social functions, which lies in permanent formation of a personality of a man as a social being and his/her preparation for accomplishing social roles, as well as in negotiating social and mental conditions for his/her life, performing social roles, consumption of culture and self-realization. 
The andragogical concept of education broadens the term education: it is not only the education of children and youth, but also of adults, and not only an intentional influence, but also a functional one, not only education, but also care.

Education is one of the basic social functions and antropics (it is how humans differ from animals).

It could be understood as:

- formation of personality of a human as a social being capable of self-realization;

- socialization in a sense of acquiring social directions and preparation for carrying out social roles;

- enculturation - introducing a person as an individual into the culture, which is the indication of human society as such and the basic characteristic of individual global societies.

Education is a complex process with two general types:

- functional influence - the influence of social environment, , unintentional, primary for the formation of a personality;

- intentional influence - deliberate, education in the narrow sense, in developed societies the core of education.

Education can be divided in terms of the content:

- care, which should be understood as the negotiation of conditions (social and mental) for the performance and self-realization of an individual and for the carrying out of his/her social roles;

- education (in its narrow sense) as learning social roles;

- education as a transfer and adoption of knowledge, skills and habits necessary for the performance of social functions.

Andragogy can be divided in terms of operationalisation into the following areas:

- education (andragogy in its narrow sense), which could be further divided into academic (university education, postgraduate education, distance learning), institutional or departmental training (banking, department of interior) and outof-school education (courses, lectures, etc.);

- education in the sense of political education, propaganda, health education, citizenship education, physical education, reeducation of delinquents, prevention of social pathologies, cultural education, military education);

- care, (culturally educational care, librarianship, occupational care, Human Resources, social care including gerontological care, entertainment, recreation, free time activities and self-realization);

- functional influences - mass media, educational work of diverse organizations and institutions. 


\section{The concept of integral andragogy}

The concept of integral andragogy operates with the premise that andragogy is not only a pedagogical discipline, which covers the education of adults. It is not a liberal art about human beings, but for human beings. This concept developed at the Palackého university in Olomouc under the leadership of docent Jochmann, prominent Czech andragogue of the 90s of the last century.

The fact, that andragogy is broadly concerned with individual and social connections of culture, economy and politics, and the need to differentiate this broad interpretation from the more narrow concept of andragogy as the theory of adult education, leads towards the use of the term Integral andragogy.

Maybe, it would be more suitable to use the term Integrative, because:

- andragogy integrates the viewpoint of several scientific disciplines on the possibilities and problems of asserting oneself in all areas of social life (in cultural, economic, and political conext);

- andragogy integrates all stages individual career;

- andragogy integrates examinations of processes and phenomena, which influence humans in the environment of permanent social changes.

The universal formulation could be the scheme of integral andragogy as an applied science about the mobilization of human resources in the environment of permanent social changes. Human resources analogically to economic resources, could be seen as a particular level of quality of members of a given society. This quality is defined by two main components:

1. cultural capital (in other words the cultural level and the ability to use information acquired not only by education, but also by the influence of the family environment, and

2. social capital (the networks of social contacts, links, relationships, etc.).

The term cultural capital was first used by the French sociologist Pierre Bourdieu, who defined it as a tool for taking over symbolic wealth, which is considered by the society to be appropriate to search for and posses.

The cultural capital together with the social capital - in other words human capital - constitute an important component of the growth potential of the given society.

In the environment of permanent changes, which is typical for the society on the border between industrialism and post-industrialism, human capital (human potential) represents the most important, but also most sensitive and vulnerable determinant of the existence and development of any society. For that reason, we need to dedicate certain care to it. Social education provides us with the theoretical base for understanding the relationship between human capital and changing 
cultural, social and economic environment. Social education is based mainly on sociology and economics, and is evidently more focused on macro-social context.

Integral andragogy may be defined as an applied science about the orientation of a human in critical intersections of his/her career or in problematic course of his/her life career. This interpretation is actually include in the above mentioned concept, however it is noticeably more focused on the individual. Social education understood as this, is much more focused on socio-therapeutic or psychotherapeutic relation with an individual, who cannot cope with his/her problems. It is evident, that the main supportive science will be psychology.

In the third variation of defining integral andragogy, we can see it as a science about the animation of an individual. Animation, never ending humanization of an individual is linked not only to enculturation (i.e. receiving and developing cultural competences), socialization and resocialization (i.e. the optimalization of social positions and roles, including soci-professional roles), but also education (i.e. intentional and goal-directed formation of an individal, his/her fostering and educating).

The sociologic interpretation of integral andragogy may be the most prospective one. Integral andragogy is considered here as a science about social and individual relations of changes in the synthetic status. This operationalization seems too abstract, and we need to explain it in more details. The social status of each person in the social structure is given by the category of status. The status is a polymorphous category, and we distinguish especially:

A) Inherent status (sex, race),

B) Assigned status (the status attained without own effort, for example: inheritance, aristocratic predicate), and

C) Acquired status (socio-economic position, which categorizes an individual into the network of social structure).

The category of acquired status can be described by several interconnected indicators. That is why it is often described as the synthetic status. Among these indicators are:

- objective characteristics of the profession held by an individual (manual work, intellectual, managing, easy, complicated, etc.),

- prestige of the profession (what kind of respect the proffesion has in the public opinion),

- qualification, education (qualification is not the same as received education)

- influence and power available to a person,

- income reached,

- lifestyle, (way of housing, free time spending, hobbies, etc.). 
In case that we change one of the given indicators, the other indicators will also change. Due to the speed of cultural, economic, political and many other changes, we see bigger or smaller changes of each indicator of individual or collective status. Integral andragogy together with social education deal with the reflection of these changes in many other dimensions and search for ways of minimizing the negative consequenes for humans. Five out of the six indicators of our social status is derived from our socio-professional position. We are what we do. In case that our fate or economic situation takes our profession away, we lose much more: the job itself, prestige of the profession, income, influence, and our education, which loses its meaning. All of this together changes our lifestyle.

The main advantage of the sociologic approach over the other approaches, and without neglecting them, lies in the complexity, systematicness and integrative access towards solutions of the examined problems.

\section{Literatura}

Mühlpachr P. (2004). Gerontopedagogika. Brno

Šimek D. (1999). Integrální andragogika. Olomouc

\section{Andragogika integralna jako wspomaganie społeczne}

\section{Streszczenie}

Koncepcja andragogiki integralnej opiera się na założeniu, iż andragogika nie jest tylko jedną z wielu subdyscyplin pedagogiki. Dyscyplina ta rozwinęła się na Uniwersytecie Palackého w Ołomuńcu w latach 90. XX wieku. Wywodzi się z andragogiki ogólnej. Jako dyscyplina naukowa bada różnice w edukacji dorosłych, dzieci oraz młodzieży - tym samym przysługuje jej status niezależnej dyscypliny naukowej. Ponadto analizuje istotny problem pojawiający się w kształceniu dorosłych: osoby dojrzałe nie są poddane procesowi wychowawczemu w wyniku ukształtowanej struktury osobowości. Andragogika integralna wpisuje się tym samym w debatę między zwolennikami koncepcji uczenia się przez całe życie a zwolennikami kształcenia rozumianego jako wsparcie udzielane osobom dorosłym. Dotyka także problemu swojego własnego statusu pośród innych nauk i relacji z pedagogiką ogólną. Stawia pytanie, czy są to dwa odrębne obszary badań, czy też dwie gałęzie nauki o edukacji, mające względnie niewielką autonomię. Stąd też ważne jest, aby wyjaśnić, czy andragogika stanowi teorię, ideologię, czy też zespół praktycznych wskazówek dla edukacji dorosłych. Dyskusyjne są także treści składające się na obszar andragogiki; debacie podlega kwestia tego, czy jest ona jedynie technologiczną i dydaktyczną koncepcją ograniczającą ją do teorii oraz praktyki edukacji i nauczania, czy też wychodzi poza te ramy i łączy wpływ wywierany na dorosłych w procesie zarządzania zasobami ludzkimi. 
Andragogika poszerza pojęcie edukacji, włączając w jej obszar poza kształceniem dzieci i młodzieży także kształcenie dorosłych; bada wpływy o charakterze intencjonalnym i funkcjonalnym; zajmuje się edukacją i opieką. Może być rozumiana jako formowanie się osobowości człowieka - istoty społecznej zdolnej do samorealizacji, jak też jako proces socjalizacji w znaczeniu nabywania ukierunkowania społecznego i przygotowania do pełnienia funkcji społecznych. Ponadto rozumieć ją można jako proces enkulturacji, tj. wdrażania jednostki do uczestnictwa w kulturze. Edukacja w tym ujęciu ma wpływ funkcjonalny, przejawiający się jako wpływ środowiska społecznego zaznaczający się w sposób nieintencjonalny, zanim nastąpi uformowanie się osobowości. Andragogika analizuje również wpływ intencjonalny, tj. edukację w wąskim sensie.

Możemy zatem w tym świetle w kategoriach operacyjnych wyodrębnić w andragogice następujące obszary: 1) edukację w wąskim znaczeniu, którą z kolei można dalej podzielić na edukację akademicką, instytucjonalną i trening obszarowy, jak i edukację pozaszkolną, 2) edukację w znaczeniu edukacji politycznej, propagandy, edukacji zdrowotnej, obywatelskiej, reedukacji przestępców, zapobiegania patologiom społecznym, edukacji fizycznej, kulturowej i wojskowej, 3) opiekę w znaczeniu opieki edukacyjno-kulturowej, zawodowej, zarządzania zasobami ludzkimi, opieki społecznej włącznie z opieką gerontologiczną, aktywności czasu wolnego i samorealizacji, 4) wpływu funkcjonalnego poprzez media masowe, pracę edukacyjną rozmaitych instytucji i organizacji.

Fakt, iż andragogika jest zainteresowana związkami indywidualnymi i społecznymi z kulturą, ekonomią i polityką, jak też potrzeba rozróżnienia tej szerokiej interpretacji wobec węższej koncepcji andragogiki jako teorii edukacji dorosłych, prowadzi nas do użycia pojęcia andragogiki integralnej. Pojęcie integralności jest w tym miejscu bardziej zasadne ze względu na to, iż andragogika integruje punkt widzenia kilku różnych dyscyplin naukowych odnośnie problemów pojawiających się w różnych obszarach życia społecznego. Co więcej, andragogika dokonuje integracji różnych etapów indywidualnych karier oraz badań nad procesami i fenomenami wpływającymi na jednostki ludzkie w środowisku permanentnej zmiany społecznej.

Andragogika integralna może być definiowana jako nauka stosowana badająca zachowania ludzi w krytycznych dla nich punktach ich kariery i jej problematycznym ukierunkowaniu. Edukacja społeczna rozumiana $\mathrm{w}$ ten sposób jest znacznie bardziej skupiona na socjoterapeutycznych i psychoterapeutycznych relacjach z jednostkami, które nie są w stanie poradzić sobie z problemami. Oczywiste jest, że najbardziej pomocną dyscypliną w tej mierze staje się psychologia.

Andragogika integralna jest także nauką badającą animację jednostki. Animacja ta bowiem jest nigdy nie kończącą się humanizacją jednostki związaną z enkulturacją (tj. zdobywaniem kolejnych kompetencji kulturowych), socjalizacją i resocjalizacją (tj. optymalizacją pozycji społecznych i ról), jak również samą edukacją (tj. intencjonalnym i nastawionym na cel formowaniem jednostki). Andragogika integralna wespół $\mathrm{z}$ edukacją społeczną zajmuje się problemem odzwierciedlenia zmian zachodzących w wielu różnych wymiarach i poszukiwaniem możliwości minimalizacji ich negatywnych skutków. Dlatego też w opisanym tutaj obszarze badawczym ważne jest, aby połączyć badania o charakterze psychologicznym z socjologicznymi, co pozwoli na uchwycenie tempa i dynamiki zmian dotykających nie tylko młode pokolenia, lecz także ludzi dorosłych. Jest to tym istotniejsze, iż aspekt społeczny determinuje w wielu przypadkach naszą pozycję zawodową. Zaletą takiego podejścia jest kompleksowość, systematyczność i integracyjny dostęp do rozwiązań badanych problemów. 